УДК 81 373.7=111

\title{
ANTHONOMASIA AS A STYLISTIC DEVICE OF CREATING PRAGMATIC EFFECT OF SPEECH
}

Hertsovska Nataliya, Voznyak Khrystyna

\section{АНТОНОМАЗІЯ ЯК СТИЛІСТИЧНИЙ ЗАСІБ СТВОРЕННЯ ПРАГМАТИЧНОГО ВПЛИВУ МОВИ}

Герцовська Н.О., Возняк К.

The article deals with antonomasia as a stylistic device of using proper name instead of a common noun or vice versa. The pragmatic effect of this trope in speech is emphasized. The types of antonomasia and different examples of it are also considered in the article. Perspectives of further research of this problem are defined.

Keywords: stylistic device, antonomasia, maxims of communication, proper name, common name, pragmatic effect.

У статті розглядається антономазія як стилістичний засіб використання власного імені замість загального або навпаки. Відзначається прагматичний ефект та функиії изього тропа у мовленні. Було проведено аналіз останніх досліджень та публікацій і вказано імена науковців, які займалися вивченням даного питання. В якості критерію стилістичного ефекту було обрано відому теорію комунікативного співробітництва Г. П. Грайса, зокрема максими комунікаиії. В статті виділяються типи антогомазії та надаються приклади до кожного з них. У наведених прикладах спостерігаємо як використання загальних імен у якості власного імені, так $і$ власного у якості загальних імен. Були згадані також випадки вживання цьвого стилістичного засобу у художній літературі. В кінці статті подані перспективи подальших досліджень иьього питання.

Ключові слова: стилістичний засіб, антономазія, максими комунікації, власна назва, загальна назва, прагматичний ефект.

Stylistic device is a conscious and intentional intensification of some typical structural and/or semantic property of a language unit (neutral or expressive) promoted to a generalised status and thus becoming a generative model.

Stylistic devices (tropes, figures of speech) unlike expressive means are not language phenomena. They are formed in speech and most of them do not exist out of context. According to principles of their formation, stylistic devices are grouped into phonetic, lexico-semantic and syntactic types. Basically, all stylistic devices are the result of revaluation of neutral words, wordcombinations and syntactic structures. Revaluation makes language units obtain connotations and stylistic value. A stylistic device is the subject matter of stylistic semasiology [1, 12].

The object of the research is antonomasia as a stylistic device.

The subject of the research is pragmatic effect of antonomasia in speech.

The study of pragmatic effect of using stylistic devices is relevant both in terms of studying the writer's individual style on the base of work of fiction and from the point of view of the general analysis of their functions. Today a new branch of stylistics is developing that is called pragmatic stylistics.

The problem of antonomasia as a stylistic device of creating pragmatic effect of speech has been studied by the following authors: E. Black, H. P. Grice, I. R. Galperin, I. M. Kochan, O. V. Yemets, V. F. Svyatovets and O. A. Halych. But this problem has not been sufficiently described.

Therefore, there is a need to outline those devices of stylistics that are most focused on creating pragmatic effect, this makes the topicality of the study. As a criterion for a stylistic effect 
there was chosen a well-known theory of communicative cooperation of H. P. Grice, in particular, maxim of communication.

The aim of the article is to investigate the pragmatic effect of antonomasia as one of the most significant stylistic devices.

Achieving this aim involves realization of such tasks:

- to explain the notion of stylistic devices;

- to define the notion of antonomasia;

- to point out its types;

- to characterize the pragmatic effect of antonomasia;

- to provide examples of using antonomasia in different situations.

A special role, in terms of stylistics, belongs to the maxim of quality that implies: do not say what you consider to be false. Grace distinguishes such devices as metaphor, hyperbole, litote and irony as special examples of deviation from the maxim of quality.

But one of the most brightly expressed stylistic trope with pragmatic orientation is antonomasia.

This variety of metaphor is based upon the principle of identification of human beings with things which surround them. People may be identified with other people, with animals, with inanimate objects and natural phenomena.

When the speaker resorts to antonomasia, he creates the so-called «talking names» which aim at depicting certain traits of human character: moral and psychological features, peculiarities of behaviour, outlook.

Antonomasia (gr. antonomasia - «naming instead») is a trope in which a proper name is used instead of a common noun or vice versa, i.e. a stylistic device, in which the nominal meaning (naming one single individual object) of a proper noun is suppressed by its logical meaning (classifying objects into classes) or the logical meaning acquires the new, nominal, component [2].

Antonomasia can provide someone with a strong epithet which further celebrates and memorializes their great deeds. In advertising and pop culture, such wording can also further celebrate the famous, such as «The Beatle»s as «The Fab Four».

Uses for antonomasia vary slightly depending on the time period. In the past, antonomasia would be used to designate class members, as oftentimes people's names were linked to their professions. Antonomasia was also used in the past to give positive names to strong warriors and negative names to weak or nasty people [2].

Here are a few examples of antonomasia in the past:

Winston Churchill as «The Great Commoner»

William Shakespeare as «The Bard»

Napoleon I «The little corporal»

In this way, the past is similar to the present, as we tend to use antonomasia purely for enjoyment and fun with nicknames.

A frequent instance of antonomasia in the Late Middle Ages and early Renaissance was the use of the term «the Philosopher» to refer to Aristotle. A more recent example of the other form of antonomasia (usage of archetypes) was the use of «Solons» for «the legislators» in 1930-s journalism, after the semi-legendary Solon, lawgiver of Athens.

There are two types of antonomasia: metaphoric and metonymic. In its turn, metaphoric antonomasia is dived into two groups [3, 4].

First, antonomasia can be in a variety of allusion. It is the use of name of a historical, or biblical personage applied to a person whose characteristic features resemble those of a well-known original.

Thus, a traitor's name may be referred to as Brutus, a ladies' man deserves the name of Don Juan. 
Another examples: Emвyd).

Every woman loves an invalid. I bring out the Florence Nightingale in them (Maprapem

Second, at ahe basis of antonomasia there can be a metaphor, i.e. the use of a common noun as a proper name. For instance, Becky Sharp, Lady Snake, Miss Ape, etc. Antonomasia of this kind is created mainly by nouns, more seldom by attributive combinations (as in «Dr. Fresh Air») or phrases (as in «Mr. What's-his-name»)

Metonymic antonomasia is usually trite and stylistically neutral. It is observed in cases when a personal name stands for something connected with the bearer of that name who once really existed. Study the following examples:

He has sold his Vandykes (Hurst).

This is my real Goya (Galsworthy).

He immediately christened me Snake-eye, the Spy, and announced that, when his braves returned from the warpath, I was to be broiled at the stake at the rising of the sun

Some former proper names are now even spelt with a small letter. For example: mack $\bullet$ intosh, sandwich, ohm (each originating from a proper name).

Antonomasia is important in literature, as it can tell more about characters just by their titles. One instance of antonomasia is the treatment of Voldemort in J.K. Rowling's Harry Potter Series. Rather than calling the dangerous man by name, all must call him «You-Know-Who» or «He-WhoMust-Not-Be-Named». This usage of antonomasia emphasizes just how dangerous the man is, as most wizards and witches are too afraid to say his actual name aloud [4, 253].

Another example of antonomasia is in Mary Shelley's Victor Frankenstein's inability to give the monster a true name is apparent in his constant use of antonomasia:

"I beheld the wretch-the miserable monster whom I had created»

«Devil, do you dare approach me?»

«Begone, vile insect!»

Antonomasia is also widely used in pop culture. For instance:

Michael Jackson as «The King of Pop»

Madonna as «The Queen of Pop»

Ella Fitzgerald as «The First Lady of Song»

Bruce Springsteen as «The Boss»

Aretha Franklin as «The Queen of Soul»

Muhammad Ali as «The Greatest»

Celebrities are constantly being given new nicknames, as is clear in the tabloids. Antonomasia can be found in movies and advertisements as well, though. Consider this collection from the television show «Lost». Sawyer constantly uses antonomasia, which gives him a playful, laid-back personality and also serves to characterize other characters based on how he chooses to name them:

Jack as «Saint Jack» and «Our Savior»: Jack is a very caring leader in the show.

Kate as «Freckles»: Freckles is a sweet, loving name for a woman he cares about.

Hurley as «International House of Pancakes»: Hurley is overweight and Sawyer is teasing

him.

Here is the list of popular antonomasia names [5]:

PERSONS:

«Mr. Soul» for Sam Cooke

«Old Blue Eyes» or «The Chairman of the Board» for Frank Sinatra

«Pelides» or «the son of Peleus» for Achilles

«Son of Laertes or «Man of Pain» for Odysseus

«The First Lady of Song» for Ella Fitzgerald

«The Führer» for Adolf Hitler

«The Gipper» or «The Great Communicator» for Ronald Reagan 
«The Great Commoner» for Winston Churchill

«The Great Emancipator» for Abraham Lincoln

«The Great Silent One» for Helmuth von Moltke the Elder

«The Greatest» for Muhammad Ali

«The Iron Chancellor» for Otto von Bismarck

«The Iron Lady» or «The Leaderene» for Margaret Thatcher

«The Queen of Pop» or «The Material Girl» for Madonna

PLACES:

«Auld Reekie» for Edinburgh

«City of Dreams» for Mumbai

«The Big Apple» for New York City

«The City of Light» for Paris

«The Eternal City» or «Urbe» for Rome

«The Smoke» for London

«The Windy City» for Chicago

So, we can say that antonomasia as special stylistic device of nominating a person always creates significant pragmatic effect. In given examples predominates the use of common names instead of proper ones that has a characterizing function. Often it is positive characterization of a person or place.

Perspectives of further research involves studying of the pragmatic effect of antonomasia, as well as other stylistic devices, on the base of work of fiction. In particular, it is interesting to see which stylistic devices promotes deviation from the maxim of quality and systematize these devices from the point of view of pragmatics.

\section{References}

1. Efimov L. P. (2004), Stylistics of English language and discursive analysis. Educational methodical manual, Vinnytsia: «New Book», 240 s.

2. Stylistic devices dictionary [E-resource], Available at: http://estylistics.blogspot.com/2012/05/antonomasia-can-be-in-way-variety-of.html, [Accessed 12 February 2018].

3. Yemets O. V. (2012), Investigating of pragmatic effect of antonomasia. Saarbrucken: LAP Lambert Academic Publishers, 69 s.

4. Arnold I. V. (2004), Stylistics. The Modern English Language. M. : Flinta, Nauka, 384 s.

5. Figures of speech. Antonomasia examples [E-resource], Available at: http://fos.iloveindia.com/antonomasia-examples.html, [Accessed 12 February 2018].

\section{УДК 159.923:378.011.3-052}

\section{СПЕЦИФІКА ПРОФЕСІЙНОЇ ІДЕНТИФІКАЦЇ̈ СУЧАСНИХ СТУДЕНТІВ} Гошовська Д.Т.

\section{SPECIFICITY OF PROFESSIONAL IDENTIFICATION OF MODERN STUDENTS} Hoshovska Daria

У статті йдеться про психологічні особливості професійної ідентифікації сучасних студентів. Встановлено, щзо набуття особистісної ідентичності висувається в ранг базових, фундаментальних потреб людини, адже засвідчує ї̈ спроможність до віднайдення власної тотожної самості як у площинах індивідуального буття, так і в просторі фахової 